Науковий вісник НЛТУ України
Scientific Bulletin of UNFU
$\begin{gathered}\text { http://nv.nltu.edu.ua } \\ \text { https://doi.org/10.15421/40290727 }\end{gathered}$

С. М. Кульман

Житомирський національний агроекологічний університет, м. Житомир, Україна

\title{
БАЗОВІ МОДЕЛІ КІНЕТИКИ ДЕФОРМУВАННЯ-РУЙНУВАННЯ ДЕРЕВНИХ КОМПОЗИЦІЙНИХ МАТЕРІАЛІВ
}

\begin{abstract}
Існуючі наразі моделі кінетики деформування і руйнування пов'язані здебільшого з описом переходу $з$ незруйнованого стану матеріалу в зруйнований в одну стадію. Це належить як до класичних теорій міцності, зокрема і кінетичної теорії міцності, так і до теорій і моделей розсіяного накопичення пошкоджень (Continuum Damage Mechanics, CDM). Метою цього дослідження було створення базових моделей кінетики деформування-руйнування (ДР), які описують цей процес у вигляді декількох послідовних переходів окремих структурних елементів (CE), у матеріалі, що деформується в часі з одного реологічного стану в інший. Для опису цього процесу залучено апарат формальної кінетики, який дає змогу, знаючи швидкість переходу СЕ з одного реологічного стану в інший, спрогнозувати час досягнення критичної концентрації зруйнованих СЕ. Встановлено, що процес ДР можна розглядати як процес поступового переходу СЕ спочатку пружного стану у в'язкопружний і потім зруйнований. Причому цей перехід може відбуватися як послідовно, так і паралельно. Таким чином, у процесі руйнування постійно змінюється число, а отже, і концентрація СЕ, які перебувають у різних реологічних станах. Зміну концентрації того чи іншого СЕ можна визначити експериментально способом вимірювання величин, що корелюють 3 параметрами ДР того чи іншого виду деформації тіла. При цьому загальне число елементів структури, що перебувають у різних станах, згідно із законом збереження мас у кожен момент часу ДР має залишатися постійним. Вперше запропоновано двостадійну нелінійну кінетичну модель втрати ресурсу за повзучості композиційних матеріалів на підставі деревини. Застосування методів формальної кінетики під час моделювання фізико-хімічних процесів, які відбуваються під час ДР, дає змогу будувати багатостадійні кінетичні моделі. Застосування методу базових діаграм деформування у поєднанні 3 двостадійним описом процесу накопичення пошкоджень дає змогу збільшити точність прогнозу допустимого часу за різних схем навантаження під час повзучості.
\end{abstract}

Ключові слова: моделі кінетики; кінетика деформування; критерії руйнування; двостадійна модель руйнування.

Вступ. Одну з перших теорій міцності сформулював Гріффітс (Griffith, 1921). Відповідно до цієї енергетичної теорії, міцність було визначено як напруження, за якого виконується умова рівності двох енергій: енергії, яка витрачається на утворення нової поверхні зростаючої тріщини, і пружної енергії, яка вивільняється завдяки зростанню тріщини. Відповідно до цієї теорії, руйнування трактують як критичну подію, яка настає за критичного напруження.

Таке трактування не підтверджується досвідом, адже відомо, що накопичення молекулярних і надмолекулярних дефектів відбувається задовго до моменту руйнування. Отже, руйнування розвивається в часі та не $\epsilon$ критичною подією. Введення тимчасового масштабу процесу руйнування призвело до створення кінетичної теорії міцності. Витоки цієї теорії належать до робіт ФТІ ім. Іоффе, які було виконано всередині минулого століття. Тимчасові залежності запропонував А. А. Александров (Aleksandrov, 2006) під час опису релаксаційних властивостей в'язкопружної деформації твердих тіл, у вигляді узагальнених рівнянь Максвелла.

Найбільш чітке та очевидне фізичне тлумачення i розвиток цих ідей надав професор С. М. Журков, який $є$ засновником кінетичної теорії міцності (Regel, Slutsker \& Tomashevsky, 1974). У цій теорії руйнування розглядають як тимчасовий процес накопичення молекулярних і надмолекулярних дефектів. Довговічність тіла під навантаженням (тобто час від створення у тілі напруження до моменту макроскопічного руйнування) визначається як фундаментальний параметр міцності та відображає середню швидкість процесу руйнування на всіх структурних рівнях: молекулярному, надмолекулярному і макроскопічному.

Фундаментальною формою кінетичної теорії міцності є рівняння Журкова. Причому рівняння Журкова, яке створене для опису механізму руйнування на молекулярному рівні, автоматично переноситься для опису механізму руйнування надмолекулярних та макрорівні, і не враховує при цьому того, як відбуваються на цих рівнях релаксаційні процеси. Окрім цього, це рівняння передбачає, що процес відбувається тільки в одну стадію. А саме зв'язки між елементами вважаються або не зруйнованими, і знаходяться під дією термосилового навантаження, або зруйнованими через час, який визначається формулою Журкова.

Мета дослідження - створення базових моделей кі-

Інформація про авторів:

Кульман Сергій Миколайович, канд. техн. наук, доцент, кафедра експлуатації лісових pecypciв. Email: sergiy.kulman@gmail.com; https://orcid.org/0000-0001-5354-5985

Цитування за ДСту: Кульман С. М. Базові моделі кінетики деформування-руйнування деревних композиційних матеріалів. Науковий вісник НлтУ України. 2019, т. 29, № 7. С. 134-141.

Citation APA: Kulman, S. M. (2019). Basic Models of Deformation-Destruction Kinetics of Wood-Based Composiets. Scientific Bulletin of UNFU, 29(7), 134-141. https://doi.org/10.15421/40290727 
нетики процесу розсіяного руйнування на підставі багатостадійного переходу структурних елементів з одного реологічного стану в інший спосіб послідовних або більш складних перетворень. Для створення кінетичної моделі релаксаційної поведінки полімеру під дією термомеханічного впливу, розглянемо декілька різних станів його окремих СЕ. Під окремими елементами структури розуміємо локальні об'єми тіла, локальні напруження в яких різні. Для кристалічного полімеру, який знаходиться під навантаженням, це можуть бути області як кристалічні, так і аморфні.

Початковий (вхідний) стан елементу структури стан, за якого зовнішній механічний вплив відсутній. У цьому випадку всі окремі елементи структури цілі та перебувають у термодинамічній рівновазі. Пружний стаціонарний стан елементу структури (П) - елемент структури, який знаходиться якийсь час у пружному стані. В'язкопружний стаціонарний стан елементу структури (В) - елемент структури у в'язкопружному стані, тобто у стані релаксації внутрішніх напружень. Зруйнований стаціонарний стан елементу структури (3) - зруйнований елемент структури, який утворюється iз в'язкопружного, напруження якого у момент руйнування розподіляються між тими елементами структури, які перебувають на цей момент часу у пружному і в'язкопружному станах.

Будемо розглядати тверде тіло не у вигляді суцільного континіуму, а у вигляді суцільної структури (конструкції), що складається 3 окремих несучих елементів структури, пов'язаних між собою певним способом. Тоді дія зовнішнього завантаження на поверхню тіла призведе до того, що його внутрішні елементи структури, внаслідок внутрішньої неоднорідності, будуть випробовувати різні за величиною і напрямком внутрішні напруження (Kulman, Boiko, 2015).

Елементи структури, напруження у яких більше від межі міцності, будуть відразу же зруйновані. Після їх руйнування зовнішні зусилля розподіляться між рештою незруйнованих елементів структури таким чином, що кожен із них буде нести нове навантаження з боку сусідніх CE.

Поведінку полімерів у часі описують переважно у вигляді комбінацій первинних реологічних тіл, таких як: пружне тіло Гука, в'язке тіло Ньютона або їх комбінацій (тіла Максвелла або Фойгта).

Комбінуючи ці первинні реологічні тіла, можна тією чи іншою мірою створити реологічну модель, поведінка якої в часі (кінетика) буде досить точно описувати поведінку реального тіла під впливом зовнішніх навантажень. Визнаним є той факт, що у період сталої повзучості тверде тіло, під дією зовнішнього температурносилового навантаження, поводиться як таке, що перебуває послідовно у пружнов'язкому, в'язкопружному або пластичному станах. При цьому, припускають, що повна деформація тіла складається зазвичай з трьох різних за своєю природою частин: миттєво оборотної (пружної), високоеластичної, оборотної в часі, тобто релаксаційної в часі (в'язкопружної) і незворотної (пластичної) (Regel, 1964). При цьому повну деформацію розуміють як загальну деформацію всього тіла, а не окремих його частин або елементів структури.

Приймемо як основну гіпотезу деформування гіпотезу про те, що, по-перше, тіло деформується i руйнується по-різному в окремих елементах структури.
А саме тільки в тих елементах, у яких локальне напруження спочатку досягає межі пропорційності, а потім межі міцності. При цьому окремий елемент структури спочатку пружно деформується, а потім переходить послідовно у в'язкопружний або пластичний стани, і потім руйнується. По-друге, окремий зруйнований елемент структури певний час оточений незруйнованими елементами структури, які перебувають у пружному або в'язкопружному стані. По-третє, тіло будемо вважати зруйнованим, якщо число зруйнованих елементів структури буде перевищувати певні наперед задані значення.

Таким чином, кінетика руйнування тіла під дією термомеханічного навантаження буде складатися з різних варіантів послідовності переходу пружних елементів структури (П) у в'язкопружні елементи структури $(B)$, а потім - у зруйновані елементи структури (3). Причому події можуть відбуватися як послідовно - П $\rightarrow B \rightarrow 3$, так і послідовно-паралельно:

$$
\left\{\begin{array}{c}
\Pi \rightarrow B \rightarrow 3 \\
\Pi \rightarrow 3
\end{array} .\right.
$$

У процесі руйнування постійно змінюється число, а отже, і концентрація елементів структури, які перебувають у різних реологічних станах. Зміну концентрації того чи іншого елементу структури можна визначити експериментально способом вимірювання величин, що корелюють із параметрами руйнування того чи іншого виду деформації тіла.

При цьому, загальне число елементів структури, що перебувають у різних станах, згідно із законом збереження мас у кожен момент часу ДР має залишатися постійним. Розгляд процесу руйнування стосовно об'єднання тріщин, наприклад дрібніших у більші, не змінює кількість структурних елементів, а тільки розглядає їх у різних станах.

Гіпотеза і обгрунтування моделі. Розглянемо варіант послідовного руйнування у дві елементарні стадії, які відбуваються одночасно в тілі за його деформування-руйнування. Схему перетворення елементів структури у процесі наведено в такому вигляді: $\Pi \rightarrow B \rightarrow 3$. Швидкість руйнування визначимо як зміну кількості зруйнованих структурних елементів $N$ в одиницю часу $t$, віднесену до одиниці об'єму тіла $V$.

Спочатку вважатимемо, що руйнування може відбувається у будь-якому об'ємі тіла (гомогенне руйнування), на відміну від гетерогенного руйнування, коли воно може відбуватися на кордонах розподілу фаз.

Швидкість руйнування запишемо: $r= \pm d N / V d t$ (для гомогенного руйнування); $r= \pm d N / S d t$ (для гетерогенного руйнування). Знак похідної означає, що витрачається або накопичується (утворюється) та чи інша кількість СС у різних станах у процесі руйнування.

Якщо під час гомогенного руйнування об'єм системи залишається постійним (закрита система), то $d N / V=d C$. Отож, швидкість руйнування пов'язана 3 концентрацією елементів структури в часі: $r= \pm d C / d t$.

Застосуємо стехіометричний закон еквівалентів до кінетики ДР, який стверджує, що відношення кількості СЕ, що змінюють свій стан, дорівнює або кратне моль величинам їх еквівалентів. Еквівалентом, у нашому випадку, є деяка частина обсягу тіла, яка, за руйнування, перетворюється в один із зруйнованих структурних еле- 
ментів. Тобто цей елемент утворюється тільки внаслідок ДР.

Застосуємо також закон кратних відносин до кількісного опису процесу ДР. Відповідно до закону кратних відносин, під час руйнування маса одного виду СЕ припадає на масу іншого виду $\mathrm{CE}$, що відносяться як невеликі цілі числа. Закон кратних відносин підтверджується дискретністю процесу руйнування, а так само тим, що всі зруйновані елементи однієї гомогенної речовини мають однакову концентрацію і чітку питому масу (об'єм).

У нашому описі процесу ДР будемо спиратися на дві концепції: по-перше, закон дії мас як закон простого процесу (елементарної його стадії); по-друге, складнощі механізму процесу ДР, що складається з тієї чи іншої сукупності послідовних або паралельних елементарних його стадій.

Закон діючих мас давно застосовують поза межами хімічної кінетики в так званих "моделях розвитку" i часто використовують у біології та екології, економіці, нейрофізіології й генетиці. Фундаментальне поняття хімічної кінетики - це механізм реакції. У широкому сенсі - це інтерпретація досвідчених даних про протікання складного процесу. У такому механізмі потрібно виділити окремі етапи і стадії процесу, описати характеристики проміжних продуктів, певні енергетичні рівні процесу тощо. Можна застосувати також вузьке розуміння механізму як сукупності стадій. Якщо стадії будуть простими, то вони складаються з елементарних реакцій як кінетичного закону, відповідно до якого ухвалюють закон дії мас або закон діючих поверхонь - для каталітичних реакцій. Саме таким поняттям механізму оперує формальна кінетика, що досліджує кінетичні моделі системи диференціальних і алгебраїчних рівнянь, відповідних механізму процесу.

Виділені вище дві концепції визначають розвиток двох ліній, які повинні доповнювати одна одну, а саме це дослідження кінетичних закономірностей елементарного акту руйнування і побудова теорії кінетики складних спільних деформацій.

Математична модель процесу деформуванняруйнування. Запишемо процес ДР тіла у вигляді зміни кількості структурних елементів, які перебувають у різних станах протягом усього часу до руйнування. Експоненціальна залежність зміни концентрації субмікротріщин, мікротріщин і макротріщин за повзучості дає підставу вважати процес делокалізованого руйнування кінетичним аналогом процесу першого порядку (Regel, Slutsker \& Tomashevsky, 1974; Petrov, Bashkarev \& Vettergen, 1993; Nosov \& Matviyan, 2017).

Основними змінними, що характеризують стан системи, визначимо кількості речовини $A_{i}$, що перебувають у різних реологічних станах. Кількість $A_{i}$ (моль) позначимо $N_{i}, n$ - компонентний вектор кількостей 3 компонентами $N_{i}-N$. Концентрацію $A_{i}$ позначимо $C_{i} \equiv N_{i} / V$.

Кожній стадії системи зіставляється іiі швидкість $W_{s}(C, T)$. Швидкість стадії $є$ величина інтенсивна і задається як функція інтенсивних величин - концентрації та температури.

Рівняння кінетики мають у координатній формі такий вигляд:

$$
\frac{d N_{i}}{d t}=V \sum_{s} \gamma_{s i} W_{s}(C, T), i=\overline{1, n},
$$

де $\gamma_{s i}$ - стехіометричний вектор 3 компонентами: $\gamma_{s i}=\alpha_{s i}-\beta_{s i}$. За відсутності автокаталізу, як у нашому випадку, цей вектор повністю визначає стехіометричні рівняння стадії.

Для кожного матеріалу існують апріорні обмеження на вектори $\gamma_{s i}$ - лінійні закони збереження (балансні співвідношення). Якщо $N_{s i}-$ кількість структурних елементів, що перебувають у певному реологічному стані $k$ - виду у молярному обсязі речовини $A_{i}$, то для будь-якого $s$ та $k$ :

$$
\sum_{i} \alpha_{s i} N_{k i}=\sum_{i} \beta_{s i} N_{k i} \text { aбо } \sum_{i} \gamma_{s i} N_{k i}=0 .
$$

Балансові співвідношення (2) породжують лінійні закони збереження для системи (4), тобто для будь-якого $k$ : $\sum_{i} \alpha_{k i} N_{i}=$ const, означає:

$$
\frac{d}{d t} \sum_{i=1}^{n} \alpha_{k i} N_{i}=V \sum_{s=1}^{m} \sum_{i=1}^{n} \alpha_{s i} \gamma_{k i} W_{s}=0 .
$$

Запишемо швидкість кожної стадії процесу деформування-руйнування, використовуючи закон дії мас. При цьому застосуємо загальну схему феноменологічної кінетики, що складається зі запису рівнянь динаміки зміни стану, виходячи із загальних уявлень та залежності процесів утворення-витрачання окремого СЕ системи:

$$
\begin{gathered}
W_{s}(C, T)=W_{s}^{+}(C, T)-W_{s}^{+}(\mathrm{C}, \mathrm{T}), \\
W_{s}^{+}(C, T)=k_{s}^{+}(T) \prod_{i} C_{i}^{\alpha_{s i}}, \\
W_{s}^{-}(C, T)=k_{s}^{-}(T) \prod_{i} C_{i}^{\beta_{s i}},
\end{gathered}
$$

де: $W_{s}^{+}(C, T)$ - функція утворення структурного елементу у стані $C_{i}$ (пружному, в'язкопружному або зруйнованому); $W_{s}^{-}(C, T)$ - функція деутворення структурного елементу у стані $C_{i}$ (пружному, в'язкопружному або зруйнованому); $k_{s}^{+/-}(T)$ - константи швидкостей переходу СЕ з одного реологічного стану в інший в $s$-стадії.

Із закону збереження мас випливає, що зміни концентрацій величин, що характеризують властивості матеріалу, або їхні зміни, під час ДР, задовольняють системі ОДУ $n$-го порядку виду:

$$
\frac{d C_{i}}{d t}=\sum_{s} \gamma_{s i} W_{s}(C, T), i=1, \ldots, n .
$$

Систему (7) визначено в деякій обмеженій області фазового простору $S:\left(0 \leq C_{i} \leq b_{i}, i=1, \ldots, n\right)-$ симплекс області процесу. Межі $b_{i}$ визначено з балансу кількості елементів структури, які перебувають у різних реологічних станах.

Для створення моделі ДР передусім складемо список об'єктів, що беруть участь у цьому процесі. Як об'єкти за аналогією із дослідженням процесів деформування i руйнування можна прийняти стан окремого структурного елементу матеріалу, який багато в чому визначає його поведінку в часі: пружне, в'язкопружне, зруйноване. Таким чином, стан матеріалу в певні моменти часу будемо визначати кількістю структурних елементів, що перебувають у тому чи іншому реологічному стані. При цьому цілий структурний елемент переходить під час його навантаження спочатку в пружний, потім - у в'язкопружний, а далі - в зруйнований стан. 
Позначимо об'єкти, що входять у матеріал в певний момент часу після його навантаження, $A_{1}, \ldots, A_{n}$. Приймемо для кінетичної моделі механізм процесу ДР у вигляді списку елементарних його стадій. Кожна стадія задається своїм стехіометричним рівнянням:

$$
\alpha_{s 1} A_{1}+\ldots+\alpha_{s n} A_{n} \rightarrow \beta_{s 1} A_{1}+\ldots+\beta_{s n} A_{n},
$$

де: $s$ - стадії; $\alpha_{s i}, \beta_{s i}$ - невід'ємні цілі числа - стехіометричні коефіцієнти.

Механізм ДР інтерпретується подальшим чином. Кожна стадія відповідає одному елементарному переходу, кожний елементарний перехід йде в один такт, в якому беруть участь тільки ті СЕ і у тих кількостях, які зазначені у стехіометричному рівнянні. Час елементарного акту $є$ значно меншим від часу між ними.

Будемо розглядати матеріал, що навантажується, як структуру, що складається із сукупності окремих структурних елементів, які перебувають під постійним зовнішнім навантаженням. Тоді стан його окремого структурного елементу в різні моменти часу можна описати таким чином:

- $A_{1} \equiv A$ - пружний стан структурного елементу (П), (elastic);

- $A_{2} \equiv B$ - в'язкопружний стан (B), (viscoelastic);

- $A_{3} \equiv C$ - зруйнований стан (3), (destroyed).

Тоді за схемою перетворення (3) буде відповідати така кінетична модель процесу деформування-руйнування:

$$
\begin{gathered}
\frac{d C A(t)}{d t}=-k_{1} C A(t) \\
\frac{d C B(t)}{d t}=k_{1} C A(t)-k_{2} C B(t) \\
\frac{d C C(t)}{d t}=k_{2} C B(t),
\end{gathered}
$$

3 початковими умовами, $t=0$ :

$$
C A(0)=1 ; C B(0)=C C(0)=0,
$$

і крайовими умовами:

$$
C A(t)+C B(t)+C C(t)=1,
$$

де: $C A(t) \in(1 \ldots 0)$ - поточна концентрація елементів структури, які перебувають у незруйнованому, пружному стані у момент часу $t ; C B(t) \in(0 \ldots 1)$ - поточна концентрація елементів структури, які перебувають у незруйнованому, тобто в'язкопружному стані у момент часу $t ; C C(t) \in(0 \ldots 1)$ - поточна концентрація елементів структури, які перебувають у зруйнованому стані у момент часу $t ; k_{1}$ - константа швидкості переходу елементів структури 3 пружного стану у в'язкопружний, $\mathrm{c}^{-1}$; $k_{2}$ - константа швидкості переходу елементів структури 3 в'язкопружного стану у зруйнований, $\mathrm{c}^{-1}$.

Результати дослідження. Розглядаючи криву тривалого навантаження, можна визначити, що ії початкова ділянка містить елементи структури тільки в пружному стані, які після зняття навантаження повертаються у недеформований стан. Протягом цього періоду пружного деформування не відбувається переходу структурних елементів у в'язко-пружний стан. Тому початком кінетики ДР приймається час закінчення пружного деформування і початок ділянки в'язкопружного деформування, тобто час початку процесу передусім несталої, а потім усталеної повзучості. Протягом усього процесу повзучості відбувається зменшення кількості незруйнованих структурних елементів, тобто тих, які перебува- ють у пружному або в'язкопружному станах, i збільшення структурних елементів у зруйнованому стані.

Для опису кінетики деформування можна порівнювати зміну концентрації СЕ у пружному стані та зруйнованому стані зі зміною величини деформації в часі. При цьому швидкість зміни концентрації в часі пружні СЕ буде пропорційна зміні швидкості деформації завдяки переходу пружних CE у в'язкопружні, а зменшення концентрації пружних СЕ буде пропорційна збільшенню абсолютної деформації процесу ДР, тобто $C A(t) \propto \varepsilon(t)$.

Оскільки зміну концентрацій СЕ, які перебувають у тому чи іншому стані, можна навести у вигляді кінетичної залежності першого порядку (Petrov, Bashkarev \& Vettergen, 1993; Regel, 1964; Regel, Slutsker \& Tomashevsky, (1974), то можна записати

$$
\frac{d C A(t)}{d t}=-k 1 \cdot C A(t) .
$$

Або, перейшовши до пропорційної ій деформації:

$$
\frac{d \varepsilon_{e}(t)}{d t}=-k 1 \cdot \varepsilon_{e}(t) \text {. }
$$

Проінтегруємо (12) після поділу змінних (час, деформація):

$$
\begin{gathered}
\frac{d \varepsilon_{e}(t)}{\varepsilon_{e}(t)}=-k 1 \cdot t, \quad \int_{\varepsilon_{1}}^{\varepsilon_{2}} \frac{d \varepsilon_{e}(t)}{\varepsilon_{e}(t)}=-\int_{t_{1}}^{t_{2}} k 1 d t \\
\ln \left(\frac{\varepsilon_{1}}{\varepsilon_{2}}\right)=-k 1\left(t_{2}-t_{1}\right), \quad k 1=-\frac{1}{\left(t_{2}-t_{1}\right)} \ln \left(\frac{\varepsilon_{1}}{\varepsilon_{2}}\right) .
\end{gathered}
$$

Отож, за зміни деформацій $\varepsilon_{1}$ та $\varepsilon_{2}$ на однакове число разів величина $k 1$ не змінюється. Це дає змогу за створення кінетичної моделі деформування-руйнування замінювати концентрації пропорційними їм величинами - деформаціями, напруженнями, імпульсами акустичної або електромагнітної емісії, кількостями речовини тощо.

Величина, зворотна константі швидкості реакції першого порядку, $\tau_{e}=1 / k 1$, має розмірність часу і характеризує за повзучості середню тривалість життя СЄ, які перебувають у пружному стані до їх переходу у в'язко-пружний стан. Аналогічно, величина, зворотна константі швидкості переходу в'язкопружного стану СЕ у зруйнований, визначає середню тривалість життя структурних елементів, які перебувають у в'язкопружному стані:

$$
\tau_{v e}=1 / k_{2} \text {. }
$$

Оскільки у формулу (13) час входить у вигляді різниці, а не у вигляді відношення як деформація, то для усунення чинника розмірності введемо безрозмірний час:

$$
\tau_{i}=t_{i} / t_{c r} .
$$

Водночас, загальну деформацію за повзучості можна уявити як суму загальних пружних і в'язкопружних деформацій, тобто деформацій внаслідок руйнування пружних і в'язкопружних СЕ:

$$
\begin{gathered}
\varepsilon_{e}+\varepsilon_{v e}=\varepsilon_{c r}, \\
t_{e}+t_{v e}=t_{c r} .
\end{gathered}
$$

Оскільки відповідно до формул (12), (14):

$$
\frac{1}{k_{1}} \dot{\varepsilon}_{e}+\frac{1}{k_{2}} \dot{\varepsilon}_{v e}=\varepsilon_{c r}, \text { то } \frac{1}{k_{1}}+\frac{1}{k_{2}}=\frac{\sum_{t_{1}}^{t_{c r}} t_{e_{i}}+\sum_{t_{1}}^{t_{c r}} t_{v e_{i}}}{t_{c r}}=1 \text {. }
$$

Вираз для $k_{2}$ отримаємо способом розв'язання системи двох рівнянь (13) і (16): 


$$
k_{2}=\frac{\ln \left(\frac{\varepsilon_{2}}{\varepsilon_{1}}\right)}{t_{1}-t_{2}-t_{c r} \cdot \ln \left(\frac{\varepsilon_{1}}{\varepsilon_{2}}\right)} .
$$

Рішення системи диференціальних рівнянь (9), (10), (11), наприклад операційним методом, дає змогу отримати значення поточних концентрацій CE, які перебувають у пружному, в'язкопружному та зруйнованому станах:

$$
\begin{gathered}
C A(t)=C A(0) e^{-k_{1} t}, \\
C B(t)=C A(0)\left(\frac{k_{1}}{k_{1}-k_{2}} e^{-k_{2} t}-\frac{k_{1}}{k_{1}-k_{2}} e^{-k_{1} t}\right), \\
C C(t)=C A(0)\left(1-\frac{k_{1}}{k_{1}-k_{2}} e^{-k_{2} t}+\frac{k_{2}}{k_{1}-k_{2}} e^{-k_{1} t}\right) .
\end{gathered}
$$

Причому, враховуючи початкові умови: $t=0$; $C A(0)=1 ; C B(0)=C C(0)=0 \quad$ i крайові умови: $t \in(0 \ldots 1): C A(t)+C B(t)+C C(t)=1$, у координатах безрозмірного часу отримаємо

$$
\int_{0}^{1} C A(t) d t+\int_{0}^{1} C B(t) d t+\int_{0}^{1} C C(t) d t=1,
$$

отже, $k 1^{-1}+k 2^{-1}=1$.

Отож, у координатах реального часу $k 1^{-1}+k 2^{-1}=t_{c r}$.

Прогнозування тривалої міцності за повзучості.

На підставі базових кінетичних моделей ДР можна реалізувати спосіб прогнозування довговічності за повзучості деревних композиційних матеріалів (ДКМ).

Завдання, яке вирішується пропонованим способом, - визначення характеристик критичної пошкодженості матеріалу та прогнозування його довговічності безпосередньо у процесі його навантаження.

Технічний результат від використання полягає у спрощенні досліджень матеріалу виробів та підвищенні точності прогнозування завдяки отриманню результатів експериментів на зразках матеріалу та виробах порівняльних форм. Окрім цього, використання запропонованого способу дає змогу застосувати результати випробувань зразків матеріалу на міцність за повзучості для прогнозу довговічності та оцінення залишкового ресурсу виробів незалежно від конструктивно-технологічних характеристик виробу завдяки використанню як параметра величини пошкодження у вигляді відношення узагальнених реологічних характеристик.

Спосіб охоплює визначення характерних параметрів пошкодження і прогнозування часу досягнення критичної позначки міри пошкодження. При цьому як запобіжне порівняння ступеня пошкодження приймаємо скалярну величину $\psi$, що дорівнює відношенню поточної концентрації зруйнованих елементів структури до поточної концентрації незруйнованих елементів структури, причому ресурс вважаємо вичерпаним за значення міри пошкодження, що перевищує $\psi_{f}$ :

$$
\psi=\frac{C C(t)}{C A(t)+C B(t)} \geq \psi_{f}=1,
$$

де $\psi_{f}-$ міра допустимої пошкодженості; $C A(t), C B(t), C C(t)$ - визначаються за формулами (18), (19), (20) відповідно; $\quad k_{1}=\frac{1}{t_{1}-t_{2}} \ln \left(\frac{\varepsilon_{1}}{\varepsilon_{2}}\right)-\quad$ константа швидкості переходу елементів структури 3 пружного стану у в'язкопружний діаграми повзучості, $\mathrm{c}^{-1} ; t_{1}-$ час закінчення ділянки пружного деформування та початку ділянки в'язкопружного деформування, с; $t_{2}$ - час виміру деформації $\varepsilon_{2}$ на ділянці сталої повзучості; $\varepsilon_{1}$ - деформація у момент часу $t_{1} ; \varepsilon_{2}-$ деформація у момент часу $t_{2} ; k_{2}=\alpha^{-1} k_{1}$ - константа швидкості переходу елементів структури із в'язкопружного стану у зруйнований, $\mathrm{c}^{-1} ; \alpha$ - параметр, який характеризує реологічні властивості (особливості) матеріалу, ступінь його непружності.

При цьому константи швидкостей переходу локальних елементів структури з одного стану в інший, що залежать від навантаження і температури, визначаються за діаграмою тривалої міцності, яка встановлює залежність зміни швидкості деформування у часі.

Спосіб реалізується подалышим чином. Будується базова діаграма деформування за ізотермічної повзучості деталі, що перебуває під постійним навантаженням за фіксованої температури в координатах: $\varepsilon-$ абсолютна деформація, мкм; $t$ - час, с. При цьому визначається час до руйнування $t_{c r}$ i максимальна деформація у момент руйнування $\varepsilon_{c r}$. Фіксується момент часу закінчення ділянки пружного деформування, $t_{1}$, а також величина деформації у цей момент $\varepsilon_{1}$ т. Після побудови базової діаграми обираємо момент часу $t_{2}=t_{c r} /(2 \ldots 3)$ і у цей момент визначаємо значення деформації $\varepsilon_{2}$. Далі за формулами (13) і (17) визначаємо значення $k 1 m a k 2$, а також величину

$$
\alpha=\frac{k_{1}}{k_{2}} \text {. }
$$

Способом виміру зміни деформації деталі в часі будуємо контрольну діаграму деформування. Обираємо момент часу $t_{2 k}$ на ділянці сталої повзучості та фіксуємо абсолютну деформацію у цей момент $\varepsilon_{2 k}$. 3 формули (16) знаходимо величину $k 1_{k}$, а з формули (23) $-k 2_{k}$.

Використовуючи формули (17)-(19), визначаємо зміну поточних концентрацій СЕ, які перебувають у пружному, в'язкопружному і зруйнованому станах. I на підставі формули (22) визначаємо прогнозований час $t_{\psi}$ досягнення граничної величини параметра пошкодження $\psi$.

Приклад реалізації способу. Використали зразки композиційного матеріалу на підставі деревини, а саме ламіновану ДСП товщиною 16 мм, фірми Кроношпан, щільністю $\rho=720 \mathrm{\kappa r} / \mathrm{M}^{3}$ Розміри зразків $400 \times 50 \times 16,1$ мм. Випробування за схемою триточкового вигину за ГОСТ 10635-88 навантаженням, що дорівнює $75 \%$ гранично допустимої. Характер поведінки системи, під дією постійного навантаження, описуємо переміщеннями середньої точки.

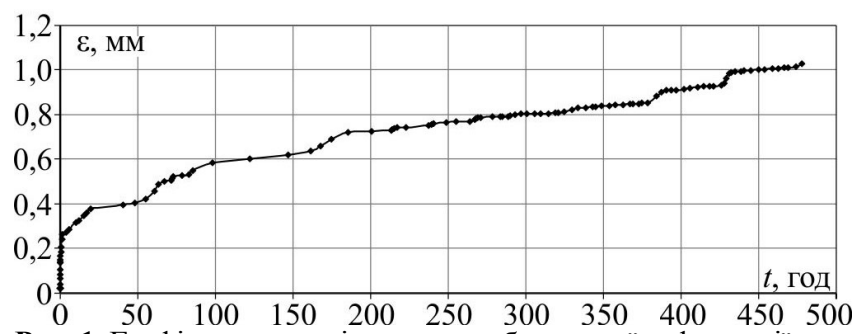

Рис. 1. Графік залежності величини абсолютної деформації за випробування ламінованого ДСП 720 кг $/ \mathrm{m}^{3}$ на згин, за напруги 18 МПа і температури $20^{\circ} \mathrm{C}$ (зразок 02.12.06.02.02) 
Експериментальними дослідженнями кривої тривалої міцності композиційних матеріалів на підставі деревної стружки, а саме стружкових плит, що ламінують (ЛДСП), було зафіксовано, що у процесі повзучості ма-
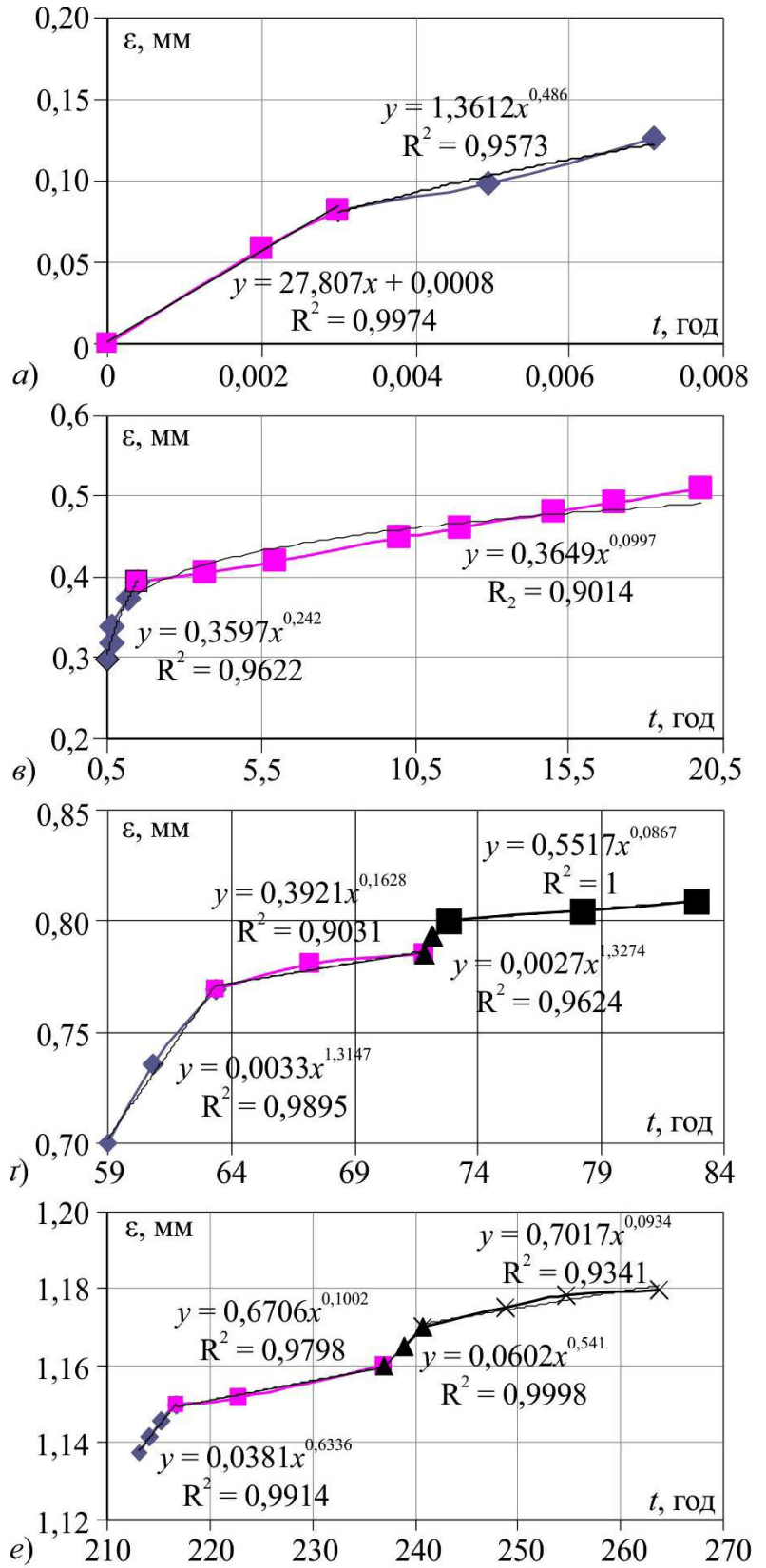

e) $\begin{array}{lllllll}210 & 220 & 230 & 240 & 250 & 260 & 270\end{array}$

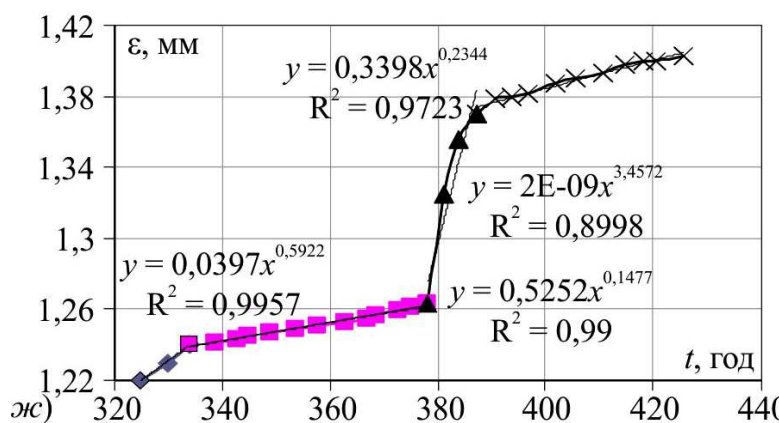

Рис. 2. Фрагменти. Зразок 02.12.06.02.02

Характер кривих деформації в часі (див. рис. 1, 2) свідчить про те, що процес $\epsilon$ нестаціонарним. Процес деформації на всіх його стадіях як на докритичній (процес стаціонарної повзучості), так і на закритичній (процес активного руйнування) відбувається нелінійно і має ступінчастий характер. теріал поводиться складним в'язкопружним чином. I крива його деформації містить ділянки, що періодично повторюються, характерні для кривих пружної і пластичної деформації (рис. 1, 2).
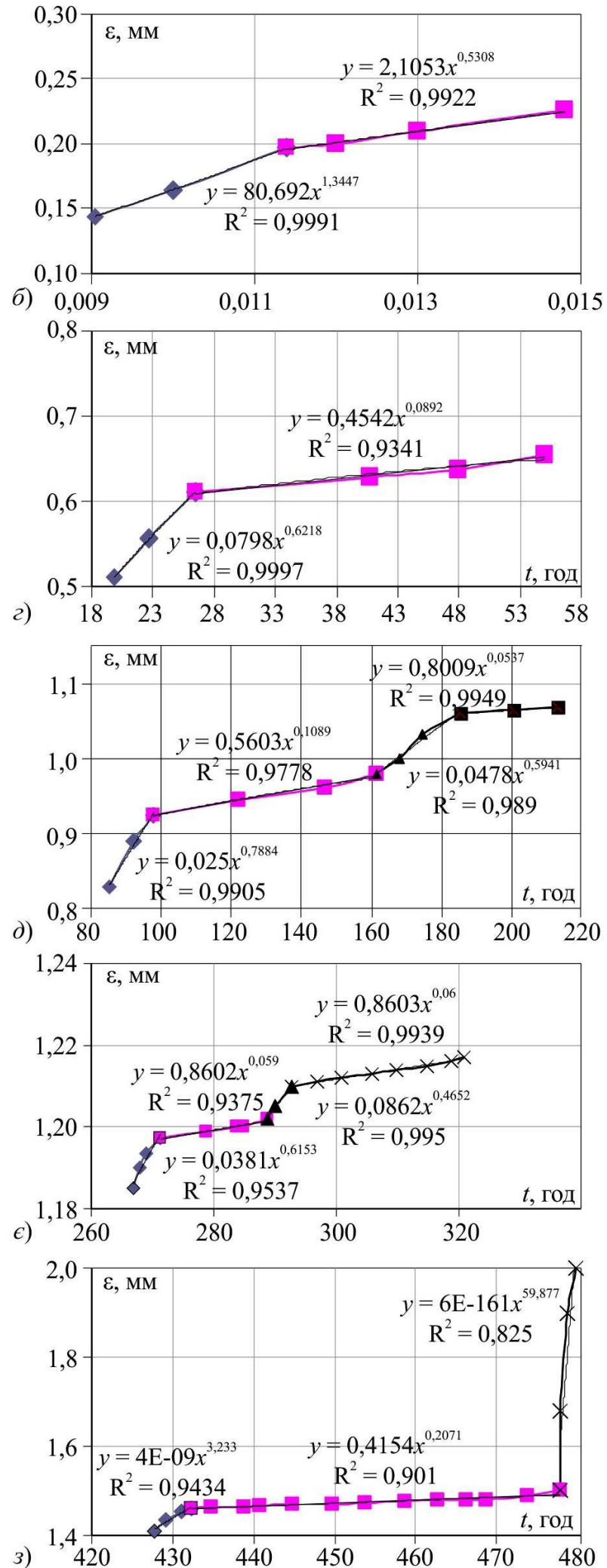

На рис. 2 зображено, що загальна крива залежності деформації в часі складається 3 окремих ділянок, які мають різну швидкість деформації, що повторюються.

У таблиці показано, що величина пластичної деформації становить у середньому 33 \% від загальної величини деформації. При цьому час пластичної деформації 
(поведінки) ЛДСП займає близько 80 \% усього часу деформації. Причому значення як величини пластичної деформації, так і їі часу знаходиться в дуже вузькому діапазоні, що свідчить про схожість процесу деформації і руйнування ЛДСП за різних умов його навантаження.

Таблиця. Величини сумарних значень пружної і пластичної деформацій зразків (Boiko, Grabar \& Kulman, 2013)

\begin{tabular}{|c|c|c|c|c|c|c|c|c|c|c|c|}
\hline \multirow{2}{*}{$\begin{array}{c}\text { № } \\
\text { 3/ח }\end{array}$} & \multirow[b]{2}{*}{ Назва зразка } & \multicolumn{5}{|c|}{ Деформація, $\varepsilon$, мм } & \multicolumn{5}{|c|}{ Час, $t$, год } \\
\hline & & разом & $\begin{array}{l}\text { плас- } \\
\text { тична }\end{array}$ & $\%$ & $\begin{array}{c}\text { крихка } \\
(m<0,6)\end{array}$ & $\%$ & разом & пластична & $\%$ & $\begin{array}{c}\text { крихка } \\
(m<0,6)\end{array}$ & $\%$ \\
\hline 1 & 03.05 .07 .03 .08 & 1,57 & 0,51 & 32,1 & 1,07 & 67,9 & 35,75 & 24,2 & 67,8 & 11,51 & 32,2 \\
\hline 2 & 21.04 .07 .03 .05 & 2,46 & 0,79 & 32,1 & 1,67 & 67,9 & 127,1 & 98,4 & 77,4 & 28,7 & 22,6 \\
\hline 3 & 02.12 .06 .02 .02 & 1,5 & 0,59 & 39,3 & 0,91 & 60,7 & 477,82 & 380,9 & 79,7 & 96,92 & 20,3 \\
\hline 4 & 04.01 .07 .02 .05 & 1,77 & 0,54 & 30,5 & 1,23 & 69,5 & 190,71 & 140 & 73,4 & 50,74 & 26,6 \\
\hline 5 & 07.10 .06 .01 .04 & 3,95 & 1,33 & 33,7 & 2,62 & 66,3 & 84 & 73,3 & 87,3 & 10,7 & 12,7 \\
\hline 6 & 11.10 .06 .01 .04 & 4,91 & 1,63 & 33,2 & 3,28 & 66,8 & 78,77 & 69,6 & 88,4 & 9,17 & 11,6 \\
\hline
\end{tabular}

Аналізуючи криві деформації в часі, загальна крива деформації аж до руйнування періодично повторює цикли пружної і пластичної поведінки.

За графіком базової діаграми деформування (базової кривої тривалої міцності) (див. рис. 1) визначимо такі величини: $t_{1}=0,003 \cdot 3600=10,8 \mathrm{c}, \quad \varepsilon_{1}=80$ мкм, $t_{2}=200 \cdot 3600=7,2 \cdot 10^{5} \mathrm{c}, \quad \varepsilon_{2}=730 \quad$ мкм, $t_{c r}=477 \cdot 3600=1,717 \cdot 10^{6}$ с. За формулами (13), (17), (23) визначимо: $k 1=0,307 \cdot 10^{-5} \mathrm{c}^{-1}, \quad k_{2}=0,719 \cdot 10^{-6} \quad \mathrm{c}^{-1}$; $\alpha=4,273$.

На рис. 3 наведено базову діаграму деформування, побудовану у координатах "концентрації CE, які перебувають у різних станах - час".

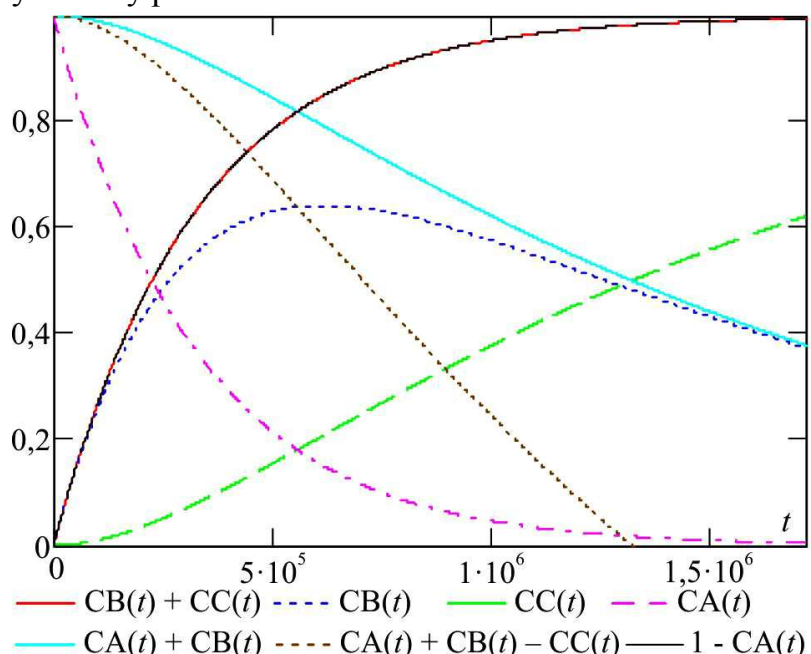

Рис. 3. Зміна концентрацій $\mathrm{CE}$, які перебувають у станах: пружний - $\mathrm{CA}(t)$, в'язкопружний $-\mathrm{CB}(t)$, зруйнований $-\mathrm{CC}(t)$ у часі для базової діаграми деформування

Контрольну діаграму деформування побудовано для аналогічної деталі навантаженням, що перевищувала базову на $15 \%$. Згідно 3 контрольною діаграмою деформування на ділянці сталої повзучості у момент часу c, $\varepsilon_{2 k}=730$ мкм.

Користуючись формулами (13), (23), визначимо значення констант швидкостей $k 1_{k}, k 2_{k}$ контрольної діаграми деформування: $k 1_{k}=-\frac{1}{\left(t_{2 k}-t_{1}\right)} \ln \left(\frac{\varepsilon_{1}}{\varepsilon_{2 k}}\right)=0.614 * 10^{-5} \mathrm{c}^{-1}$; $k 2_{k}=\alpha^{-1 *} k 1_{k}=0.144 * 10^{-5} \mathrm{c}^{-1}$.

Критична величина пошкодження буде досягнута у той момент, коли, виходячи з умови (22):

$$
C A\left(t_{\psi}\right)+C B\left(t_{\psi}\right)-C C\left(t_{\psi}\right)=0 .
$$

Розв'язуючи спільно рівняння (18)-(20) і (24), знайдемо час до руйнування, що прогнозується: $t_{\text {прогнозч }}=6,6 * 10^{5}$ с. Фактичний час до руйнування контрольного зразка становить $t_{\text {фактн }}=6,7 * 10^{5} \mathrm{c}$.

На рис. 4 зображено контрольну діаграму деформування, побудовану в координатах "концентрації СЕ, які перебувають у різних станах - час", яка наочно показує процес втрати несучої здатності деталі в часі під час повзучості.

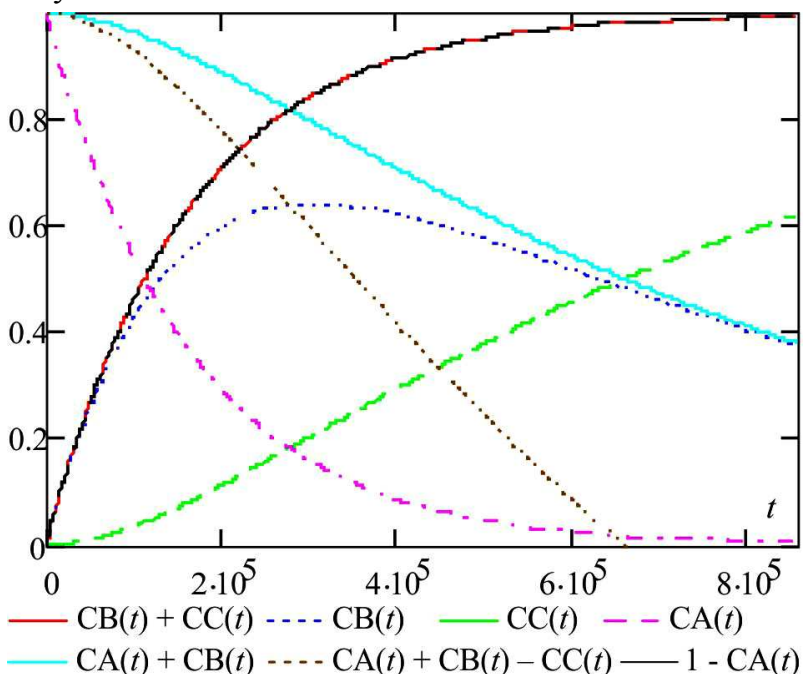

Рис. 4. Зміна концентрацій $\mathrm{CE}$ які перебувають у станах: пружний $-\mathrm{CA}(t)$, в'язкопружний $-\mathrm{CB}(t)$, зруйнований $-\mathrm{CC}(t)$ у часі для контрольної діаграми деформування

Висновки. На підставі аналізу отриманих результатів теоретичних і експериментальних досліджень процесу деформування-руйнування деревних композиційних матеріалів можна зробити такі висновки:

1. Вперше запропоновано двостадійну нелінійну кінетичну модель втрати ресурсу за повзучості композиційних матеріалів на підставі деревини.

2. Застосування методів формальної кінетики за моделювання фізико-хімічних процесів, які відбуваються під час деформування-руйнування, дає змогу будувати багатостадійні кінетичні моделі.

3. Застосування методу базових діаграм деформування у поєднанні 3 двостадійним описом процесу накопичення пошкоджень дає змогу збільшити точність прогнозу допустимого часу за різних схем навантаження під час повзучості.

\section{Перелік використаних джерел}

Aleksandrov, A. A., \& Aleksandrov, A. P. (2006). Sobranie nauchnykh trudov. (In 5 vol.). Fizika tverdogo tela. Fizika polimerov. (Vol. 1). In P. A. Aleksandrov, L. V. Kravchenko, V. K. Popov (Compilers), Zh. I. Alferov (Main Ed.), 333 p. [In Russian].

Boiko, L. M., Grabar, I. G., \& Kulman, S. M. (2013). Dovhovichnist lychkovanykh struzhkovykh plyt u konstruktsiiakh mebliv. Kiev: Education of Ukraine, 210 p. [In Ukrainian]. 
Griffith, A. A. (1921). The phenomena of rupture and flow in solids". Philosophical Transactions of the Royal Society of London, A, 221, 163-198.

Kulman, S. M. (2011b). Neliniini efekty deformuvannia i ruinuvannia kompozytsiinykh materialiv na osnovi derevyny. (Ser. Lisivnytstvo ta dekoratyvne sadivnytstvo). Scientific Bulletin of National University of Life and Environmental Sciences of Ukraine, 164(1), 250255. [In Ukrainian].

Kulman, S. M. (2011a). Kinetyka tryvaloi mitsnosti kompozytsiinykh materialiv na osnovi derevyny. Suchasni problemy zbalansovanoho pryrodokorystuvannia: 6th scientific-practical conference, (pp. 196-206). Kamyanets-Podilsky: PDATU. [In Ukrainian].

Kulman, S. M. (2013). Neliniina dynamichna model deformuvannia ta ruinuvannia kompozytsiinykh materialiv na osnovi derevyny. (Ser. Lisivnytstvo ta dekoratyvne sadivnytstvo). Scientific Bulletin of National University of Life and Environmental Sciences of Ukraine, 185(2), 312-319. [In Ukrainian].
Kulman, S. M., \& Boiko, L. M. (2015). Kinetic model of long durability of porous composite materials based on wood. Sovremennye stroitelnye materialy iz metalla $i$ drevesiny: sbornik nauchnykh trudov. Odesa: OOO "Vneshreklamservis", 134 p. [In Russian].

Nosov, V. V., \& Matviyan, I. V. (2017). Mekhanika neodnorodnykh materialov. (2nd ed.). St. Petersburg: Publishing House "Lan", 276 p. [In Russian].

Petrov, V. A., Bashkarev, V. I., \& Vettergen, V. I. (1993). Fizicheskie osnovy prognozirovaniia dolgovechnosti konstruktcionnykh materialov. St. Petersburg: Politekhnika, 475 p. [In Russian].

Regel, V. R. (1964). Vysokomolekuliarnye soedineniia, 6, 395. [In Russian].

Regel, V. R., Slutsker, A. I., \& Tomashevsky, E. E. (1974). Kineticheskaia priroda prochnosti tverdykh tel. Moscow: Science, 560 p. [In Russian].

S. M. Kulman

Zhytomyr National Agroecological University, Zhytomyr, Ukraine

\section{BASIC MODELS OF DEFORMATION-DESTRUCTION KINETICS OF WOOD-BASED COMPOSIETS}

Existing models of kinetics of deformation and destruction are related mainly to the description of the transition from the undamaged state of the material destroyed into one stage. This applies both to classical theories of strength, including the kinetic theory of strength, and to the theory and models of damage accumulation (Continuum Damage Mechanics (CDM)). The purpose of this study was to create the basic models of kinetics of deformation-destruction, which describe this process in the form of several successive transitions of separate structural elements (SE), in a material that deforms from one rheological state to another in time. To describe this process is involved a formal kinetics apparatus, which allows, knowing the speed of the transition of the SE from one rheological state to another, predicting the time to reach the critical concentration of destroyed SE. It is established that the process of deformation-destruction can be considered as a process of gradual transition of the SE first of an elastic state, into viscoelastic and then destroyed. Moreover, this transition can occur both sequentially and in parallel. Thus, in the process of destruction, the number, and hence the concentration of SE, which are in different rheological states, is constantly changing. The change in the concentration of one or another SE can be determined experimentally by measuring the quantities that correlate with the parameters of deformation-destruction of one or another type of deformation of the body. In this case, the total number of elements of the structure, which are in different states, according to the law of conservation of masses at each time of deformationdestruction must remain constant. For the first time, a two-stage nonlinear kinetic model of resource loss with creep of composite materials based on wood is proposed. The application of formal kinetics methods in the simulation of physical-chemical processes that occur during deformation-destruction allows us to build multi-stage kinetic models. The application of the method of basic deformation diagrams in conjunction with the two-stage description of the process of accumulation of damage can increase the accuracy of the prediction of allowable time for different load patterns during creep.

Keywords: models of kinetics; kinetics of deformation; criteria of destruction; two-stage model of destruction. 